\title{
Performed Observation Result Reported Date
}

National Cancer Institute

\section{Source}

National Cancer Institute. Performed Observation Result Reported Date. NCI Thesaurus.

Code C93941.

The date (and time) on which the result is reported. 